\title{
Individual Characteristic and the Causes of Death in Lecturers at Jambi, Indonesia
}

\author{
Ummi Kalsum ${ }^{1}$, Helmi Suryani Nasution ${ }^{2}$, Ismi Nurwaqiah Ibnu ${ }^{3}$ \\ 1,2,3 Public Health Study Program, Medicine and Health Sciences Faculty, Universtas Jambi \\ *Corresponding author. Email: ummi2103@unja.ac.id
}

\begin{abstract}
Work as a lecturer is highly risk because of the workload, stress and unhealthy eating patterns or lifestyles as well as levels of welfare that are not proportional to performance demands. Recently, there has been an increasing number of premature deaths due to non-communicable or degenerative diseases. The research objective was to determine the characteristics and causes of death among lecturers in Jambi (case study at Jambi University). The research design was cross sectional. Data collection by interview and documentation in the staffing section and the family of lecturers who died. Data collection time for 2 months (July-August 2020). The number of lecturers who died during 2015-2020 was 25 people (2.5\%). The average number of lecturers who died was 5 people/year. Characteristics of Lecturers who died were mostly male (76\%), with an average age of 59.8 years (minimum 37 and maximum 68 years). The average working period is 30.64 years (minimum 13 and maximum 39 years). Lecturers pass away at the elderly (68\%), associate Professor position (56\%), work period of more than 30 years $(64 \%)$, postgraduate education (64\%), Bachelor of Law study program (20\%), Faculty of Teacher Training and Science Education (40\%), occurred most in 2018 (28\%). The cause of death was non-communicable diseases (96\%), especially Diabetes Mellitus (28\%), Heart Attack, Hypertension, Liver Cancer and Auto Immune diseases. Non-communicable diseases as the main cause of death among lecturers, it is more often in women, doctoral education level, a functional position as a Professor, a work period of more than 30 years and from the Faculty of Social Humanities Literacy. It is necessary to prevent non-communicable diseases by implementing "CERDIK" behavior (regular health checks, no smoking, being active in physical activity/sports, a balanced diet, adequate rest and good stress management).
\end{abstract}

Keywords: cause, death, lecturer, non-communicable disease.

\section{INTRODUCTION}

In 2016, degenerative diseases or non-communicable diseases (NCD) accounted for $71 \%$ (41 million) of deaths in the world. The main types of NCD that contributed to death among the total deaths due to NCD were cardiovascular disease $(44 \%)$, cancer $(22 \%)$, chronic respiratory disease (9\%), and diabetes (4\%). The proportion of deaths due to NCD in Indonesia is almost the same as the proportion of deaths at the global level. In Indonesia, it is estimated that the proportion of deaths due to NCD is $73 \%$, which $35 \%$ come from cardiovascular disease, $12 \%$ from cancer, $6 \%$ from chronic respiratory diseases, and $6 \%$ from diabetes [1].

NCD has also been linked to causes of premature death. It is estimated that the risk of premature death due to NCD at the age of 30-70 years in Indonesia is 26\% [1]. In addition to death, NCD also causes economic losses for a country. This is due to high dependency rates, loss of work productivity, decreased access to production factors which in turn leads to low economic growth and poverty [2]. The results of Basic Health Research (RISKESDAS) in 2018 indicate that the behavior of the Indonesian population is at risk for the occurrence of NCD [3].

The Golestan Cohort Study, which is a populationbased study with respondents aged $<70$ years, concluded that ischemic heart disease and stroke were the main causes of death. With an increase in socioeconomic status and physical activity, reducing opium and cigarettes, increasing vegetable/fruit consumption, and controlling hypertension and diabetes, it can reduce the incidence of premature death [4]. Another risk factor associated with cardiovascular death is stress at work. Workers with a high job strain (high job demands and low job control) 
and an imbalance between effort and reward have an increased risk of experiencing cardiovascular death [5].

Research on the risk factors for NCD is quite a lot done in the general population. However, there has been no research on the identification of risk factors for NCD and premature death among lecturers in Indonesia, especially in Jambi Province. Lecturers are a professional group that needs to be researched because lecturers are at risk of being exposed to NCD as a result of work, stress and unhealthy diet/lifestyle as well as a level of welfare that is not proportional to their performance demands. Based on the existing phenomena, many lecturers died at a young age. Researcher's provisional estimates are workload, level of welfare, and lifestyle. Lecturer is a job with a heavy load. They must carry out the Tri Dharma of Higher Education, namely education (take course to their students), research, and community service at the same time which must be reported as a load of performance every semester. Meanwhile, the salary earned is not sufficient. As a result, lecturers ignore healthy living behaviors such as lack of rest and exercise, neglecting meal times, and high stress $[6,7]$.

It is necessary to do research on the proportion of deaths, description of characteristics, and risk factors for NCD among lecturers in Jambi Province, Indonesia. The results of this research are expected to be able to design preventive efforts and improve the health status of lecturers, the basis for planning intervention activities and policies as outlined in the policy brief as a basis for input for policy making, especially for the Ministry of Education and Culture, Ministry of Health, Local Government and Jambi University itself as a research locus.

The research objective was to determine the characteristics and causes of death among lecturers in Jambi (case study at Jambi University), Indonesia in the last five year period.

\section{METHODS}

The research design was cross sectional. The target population was 3,665 lecturers in Jambi Province and 1016 of them as a lecturers at Jambi University. The sample were 25 lecturers who died in the 2015-2020 period at Jambi University (total sample), in the last five years period. Data collection time was carried out for 2 months (July-August 2020).

The variables in this study were individual characteristics (gender, age at death, functional position, years of service, rank/class of space, education level, study program, faculty, year of death) and cause of death.

Primary data was obtained by interviewing and record from the Jambi University staffing department, the Deans or Deputy of Deans. Researchers also conducted in-depth interviews with deceased Lecturers' families (husband / children / siblings) to complete exploring the data of disease history. About 25 Lecturer families visited, only 15 families were successfully met and were willing to be interviewed (60\%).

Among 25 lecturers, $15(60 \%)$ of the lecturers' families were successfully interviewed. One person $(4 \%)$ of the lecturer's family could not be found the address, and $9(36 \%)$ families who could not be interviewed refused, no family could be interviewed, or there was no response. Data on age, gender, functional position, rank and class, years of service, level of education, origin of study program / faculty can be presented in full. This data is obtained from data available in the Personnel section of Jambi University. Meanwhile, other data is only presented from 15 lecturers whose families were successfully interviewed.

In order to obtain a proportional picture, it is necessary to know the number of lecturers at Jambi University. In this study, the number of Jambi University lecturers was taken from the website of the Higher Education Database which was accessed on 10 October 2020.

Univariate analysis used descriptive statistics (average, median, minimum-maximum, standard deviation) on the age and years of service as well as the frequency distribution of the variables studied in this research and cross tabulation.

\section{RESULT}

The proportion of the incidence of death among lecturers in Jambi University during 2015-2020 was $2.5 \%$. The average number of lecturers who died was 5 people/year. Characteristics of lecturers who died were $76 \%$ male, with an average age of 59.8 years (a minimum age of 37 years and a maximum of 68 years). The average working period was 30.64 years (minimum 13 years and maximum 39 years) (table 1 ).

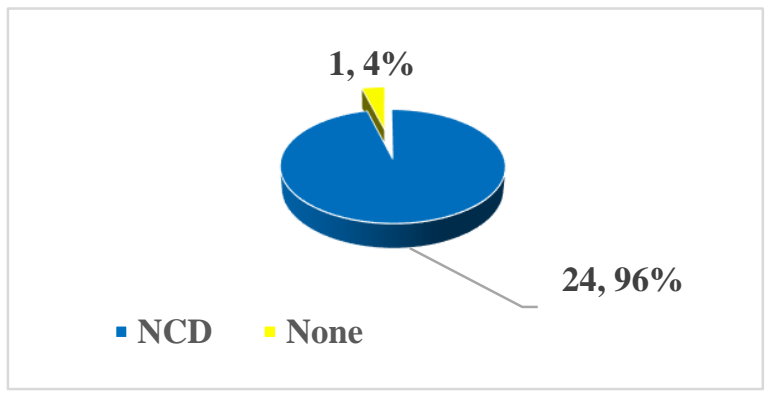

Figure 1. Distribution of Causes of Death among Lecturers in Jambi 


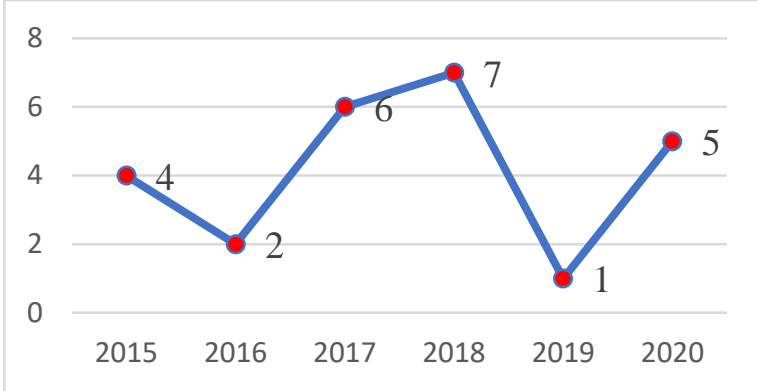

Figure 2. Trend of Number of Death among Lecturer in Five Years (2015-2020) at Jambi University

Figure 2 shows a very fluctuating trend of mortality among lecturers in the last five years in University of Jambi as the only largest and oldest State University in Jambi Province.

Table 3 Causes of death among Jambi University lecturers in the last 5 years $(n=25)$

\begin{tabular}{lcr}
\hline Cause of Death & n & \multicolumn{1}{c}{$\%$} \\
\hline Auto Immune & 2 & 8.0 \\
\hline Diabetes Mellitus (DM) & 3 & 12.0 \\
\hline $\begin{array}{l}\text { DM and complications (heart, } \\
\text { abscess) }\end{array}$ & 1 & 4.0 \\
\hline $\begin{array}{l}\text { DM and complications (heart } \\
\text { attack) }\end{array}$ & 1 & 4.0 \\
\hline DM, Obesity, Gout & 1 & 4.0 \\
\hline $\begin{array}{l}\text { DM, Tuberculosis, Heart } \\
\text { Disease }\end{array}$ & 1 & 4.0 \\
\hline Chronic Gastritis & 1 & 4.0 \\
\hline Hypertension (HT) & 2 & 8.0 \\
\hline HT and Cholesterol & 1 & 4.0 \\
\hline Heart cancer & 2 & 8.0 \\
\hline Gastric Cancer and DM & 1 & 4.0 \\
\hline Lymphoma Cancer & 1 & 4.0 \\
\hline Lymph gland & 1 & 4.0 \\
\hline Liver & 1 & 4.0 \\
\hline Heart attack & 3 & 12.0 \\
\hline Stroke and Heart & 1 & 4.0 \\
\hline Stroke and Brain Tumor & 1 & 4.0 \\
\hline Painless & 1 & 4.0 \\
\hline & & \\
\hline
\end{tabular}

Lecturers who died were mostly at the age of $>=60$ years (elderly), with functional positions as an Associate Professor $(56 \%)$, years of service as lecturer above 30 years $(64 \%)$, graduate education $(64 \%)$, most came from the Bachelor of Law Study Program (20\%), Faculty of Teacher Training and Education (40\%), and most died in 2018 (28\%) (table 2).

The most common cause of death was from degenerative diseases or non-communicable diseases which reached $96 \%$ (Graph 1), especially the causes of death were Diabetes Mellitus and Diabetes Mellitus with complications (28\%), followed by Heart Attack, Hypertension, Liver Cancer and Auto Immune, only one person of lecturer died without any previous illness (table 3).

The cause of death among the lecturers were noncommunicable diseases, it was more common in the female group (100\%), had a doctoral education level, a functional position as a Professor, a work period of more than 30 years and from the Faculty or Social Humanities department. Faculty of Teacher Training and Education, law, economy and business (table 4).

\section{DISCUSSION}

Jambi University as the locus of this research is the largest and only state university in Jambi Province with more than 1000 lecturers spread across Six Faculties and 81 study programs from undergraduate to Doctoral programs.

This study found, although there was only a small proportion of premature death among lecturers at Jambi University, the most dominant pattern of causes of death was due to non-communicable diseases, especially suffered from Diabetes Mellitus and its complication.

From the data obtained, the minimum age of the lecturers who died was 37 years and the maximum was 68 years. The average lecturer who died was 59.80 years and the median was 61 years. There are 8 lecturers who died before entering elderly. This indicates that the average lecturer dies before the elderly and the life expectancy of lecturers is below to the life expectancy of the general population.

In general, elderly condition if they are 65 years and over. In Indonesia, the elderly are aged 60 and above. This is confirmed in Law Number 13 of 1998 concerning the welfare of the elderly in Chapter 1 Article 1 Paragraph 2. According to the Indonesian Ministry of Health (2015) elderly are classified into elderly (60-69 years) and elderly with high risk (more of 70 years or older with health problems). Whereas WHO calculates the elderly into 4 groups, namely middle age if aged 45-59 years, elderly if aged 60-74 years, old if aged 75-90 years and very old if aged $>90$ years $[8,9]$.

If calculated as a percentage based on gender, the percentage of male lecturers who died was $4 \%(19 / 520)$ or compared to women, namely $1 \%(6 / 454)$. This is in accordance with the data that the life expectancy age of women is higher than men. In Indonesia, the life expectancy of the Indonesian population in 2017 was 73.9 years for women and 69.2 years for men [10]. Meanwhile, at the global level, it is stated that the average age of women is 6-8 years longer than men. This is due to reasons of biological and behavioral differences [11] 
It can be seen that almost all of the male respondents stated that they did not do heavy or moderate physical activity and most of them smoked. Increasing physical activity and reducing smoking can reduce the incidence of premature death [4]. followed by doctoral degree, namely $3 \%$ (8 of 257 ) and Master degree ( $2 \%$ of 689 ). The high mortality rate for lecturers with an undergraduate education level may not be representative because the number of lecturers with an undergraduate education at Jambi University is very

Table 4. Cross tabulation between the characteristics of Lecturers and the types of diseases that cause of death

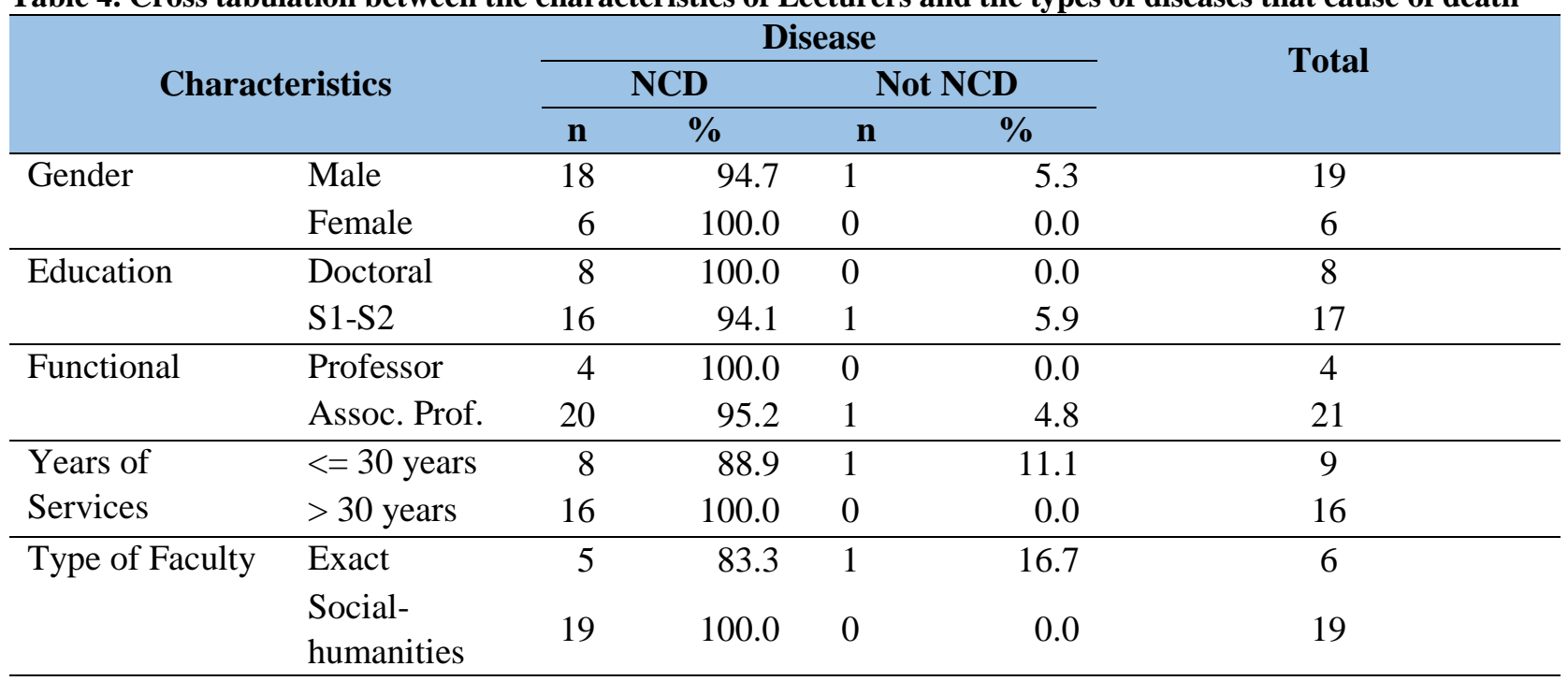

Based on functional positions, if it is calculated based on the number of existing lecturers, the percentage of lecturers who have experienced the most deaths is professor, then followed by associate Professor and assistant Professor. This shows the impression that the higher the functional position, the higher the percentage of lecturers who die. The functional position in this study is assumed to be a proxy for the workload. Another risk factor associated with cardiovascular death is stress at work. Workers with a high job strain (high job demands and low job control) and effort-reward (an imbalance between effort and reward) have an increased risk of experiencing cardiovascular death [5]. As a research conducted in Semarang, which states that lecturers have a high burden in education and guidance as well as a fairly high burden of psychological research pressure ("Analysis of the Mental Workload of Undip Industrial Engineering Lecturers with the Subjective Workload Assessment Technique (SWAT) Method," 2012). The lecturer group is a relatively tough job but the incentive rewards are still relatively low [12].

The class of space is considered to be in line with the length of service even though there were 2 peoples ( $8 \%$ ) who have worked more than 30 years but are still in Level of group III. Age, years of service, and class rank of lecturers are more related to the commitment of lecturers to the University [13]. Therefore, this variable is not discussed in relation to mortality among lecturers, especially if it is associated with non-communicable diseases.

The percentage of lecturers who died based on their education level was more for lecturers with an undergraduate education, namely $10 \%$ (out of 10), small, only 10 peoples.

The percentage of lecturers who died based on the origin of the study program varied, namely in the range of $1 \%-25 \%$. However, in general the pattern of mortality by study program cannot be concluded clearly. This is because the number of lecturers in each study program is mostly small so that the proportion figure is not representative enough to state whether the proportion is large or small. However, if grouped into a larger group, namely the level of education, the proportion of lecturers who died mostly teaching at the Doctoral degree was $6 \%$ (1 in 17), followed by lecturers who taught at the master level and Diploma 3 levels, namely 5\% (5 out of 109 for master and 3 out of 60 for Diploma 3), and lecturers teaching at Bachelor degree was $2 \%$ (16 out of 798). For the undergraduate level, it can be seen that the Law Faculty and the Teacher Training Faculty have a large proportion of lecturers with a fairly large number of deaths, namely $6 \%$ (5 of 82) for the Law Faculty and 3\% (6 out of 219) for the Teacher Training Faculty. When viewed from the risk factors for non-communicable diseases, it appears that there is no difference in the proportion of lecturers who die by faculty. This can be seen from the description of risk factors for infectious diseases that are distributed almost the same in all faculties, namely workload, rest patterns, physical activity, and smoking habits.

The proportion of lecturers who died describes the age of the respondent at death. As previously discussed, that some lecturers died before elderly and the life expectancy of lecturers was below than the life expectancy of the general population. This is what then led to the term premature death that occurs among 
lecturers, because most die at the age of being active in work because of the relatively longer retirement age.

Most of the lecturers' cause of death was due to degenerative diseases. When viewed from the 2017 national data, it is stated that the top five causes of death in Indonesia are stroke, ischemic heart disease, diabetes mellitus, tuberculosis, and liver cancer [9]. Meanwhile, this sequence is slightly different from the sequence of causes of death for lecturers at Jambi University where the first order is diabetes mellitus (with or without complications) followed by heart attack, hypertension, liver cancer, and auto immunity. The cause of death that occurred among lecturers at Jambi University was mostly due to non-communicable diseases which were closely related to the risk of an unhealthy diet and lifestyle.

The results of the study (shown in table 4), reveal that male lecturers, with a master degree, with a work period of more than 30 years and coming from the faculty of social and humanities have a higher percentage of death from non-communicable diseases The final adult age group (> 35 years) is the age group at risk for developing health problems due to degenerative processes, plus the workload at that time. This is in line with the research of Indriyati, et al. (2020) on 180 lecturers and staff at the MH Thamrin University, Jakarta, which stated that the age group more than 35 years had a higher proportion of pre-metabolic syndrome $(44.9 \%)$ than those aged $<35$ years. A prevalence ratio of 1.95 indicates that those aged more than 35 years have an almost 2 times higher risk of developing pre-Metabolic Syndrome, which later becomes the forerunner of degenerative diseases [14]. Likewise, the results of research on 110 employees at Sriwijaya University, stated that male employees, over 38 years old and working / serving between 12-36 years, are the ones with the highest percentage of noncommunicable diseases such as coronary heart disease and hypertension [15].

The age and gender factors really influence the development of degenerative diseases. Based on the results of research in other areas with different types of work, it was found that the female gender was more at risk of contracting non-communicable diseases due to postmenopausal factors. The interaction between various risk factors for cardiovascular disease and hormones can play a role in the development of coronary heart disease [16]. Unlike the case with this study where the percentage who experienced non-communicable diseases were men, lecturers and had functional positions as assistant professor or associate Professor. This result is supported in other research on 76 employees of the case and control groups, namely that of the 10 variables there are 3 variables that are proven to be at risk of degenerative disease incidence, namely gender, type of work and behavior while with an overall percentage of $75 \%$. This means that male employees, structural work and behavior of $\geqslant 6$ hours / day have a probability of experiencing hypertension by $75 \%$, while $25 \%$ is influenced by other factors [17].

Based on the results of this study, what is unique is that the lecturers from the socio-humanities faculty suffer more from non-communicable diseases than the lecturers in the exact science faculty, this is because the lecturers in the exact sciences pay more attention to their health, know when to schedule a check-up, feel signs of pain, because some courses teach about it. Unlike the social and humanities lecturers who are less exposed to health information. This result is supported by research by Wati, et al. (2016) on lecturers at Udayana University, which stated that respondents with a background in health science and teaching at the health faculty had a higher percentage of checking their health compared to lecturers with a non-medical background. The research shows that lecturers at Udayana University as health educators have been responsive to health problems by conducting medical check-ups as an effort to detect health problems, especially in PTM, and this is not found in non-health teaching lecturers [18].

The results of this study found that a job as a lecturer has a very large risk of developing degenerative diseases which are the main causes of death at this time, both among the general population, especially among lecturers. Education and literacy efforts are needed about the prevention of these diseases by cultivating and implementing healthy life habits through routine physical activity and consuming a balanced nutritious diet, adequate rest patterns, managing stress, not smoke and routinely carrying out health checks such as measuring blood pressure, check blood glucose levels, cholesterol and other health checks.

\section{CONCLUSION}

The incidence of death among lecturers was mostly due to non-communicable diseases such as diabetes mellitus, heart disease, hypertension, cancer, autoimmune and stroke. Although the proportion of the incidence of death among lecturer to the population is only $2.5 \%$, NCD as the main cause of death needs to be anticipated due to the burden and rhythm of work that demands high performance and concentration. Causes of death are diseases related to unhealthy lifestyle and poor diet. It is very necessary to prevent non-communicable diseases by carrying out and cultivating "CERDIK behavior" (Regular health checks, no smoking, being active in physical activities or sports, a balanced diet, adequate rest and stress management). 
Table 1. Numerical conclusions according to the age and tenure of the lecturers $(n=25)$

\begin{tabular}{lcccc}
\multicolumn{1}{c}{ Characteristics } & Min-Max & Mean $(\mathbf{9 5 \%}$ CI) & $\begin{array}{c}\text { Standard } \\
\text { Deviation }\end{array}$ & Median \\
\hline Age (year) & $37-68$ & $59.80(57.22-62.38)$ & 6.25 & 61 \\
\hline $\begin{array}{l}\text { Tenure of lectures } \\
\text { (year) }\end{array}$ & $13-39$ & $30.64(28.35-32.93)$ & 5.56 & 32 \\
\hline
\end{tabular}

Table 2. Characteristics of Lecturers who death in the last 5 years at Jambi University $(n=25)$

\begin{tabular}{|c|c|c|c|}
\hline Variables & Category & $\mathbf{n}$ & $\%$ \\
\hline \multirow[t]{2}{*}{ Gender } & Male & 19 & 76.0 \\
\hline & Female & 6 & 24.0 \\
\hline \multirow[t]{2}{*}{ Age at Death } & Not elderly & 8 & 32.0 \\
\hline & Elderly & 17 & 68.0 \\
\hline \multirow[t]{3}{*}{ Functional Level } & Assistant Professor & 7 & 28.0 \\
\hline & Associate Professor & 14 & 56.0 \\
\hline & Full Professor & 4 & 16.0 \\
\hline \multirow[t]{2}{*}{ Rank/Class } & Rank Level 3 & 6 & 24.0 \\
\hline & Rank Level 4 & 19 & 76.0 \\
\hline \multirow[t]{2}{*}{ Years of service } & $<=30$ years & 9 & 36.0 \\
\hline & $>30$ years & 16 & 64.0 \\
\hline \multirow[t]{3}{*}{ Education Level } & Bachelor & 1 & 4.0 \\
\hline & Master & 16 & 64.0 \\
\hline & Doctoral & 8 & 32.0 \\
\hline \multirow[t]{20}{*}{ Study Program } & Third Diploma of Chemical Analyst & 1 & 4.0 \\
\hline & Fourth Diploma of Regional Finance & 1 & 4.0 \\
\hline & Fourth Diploma of Government Management & 1 & 4.0 \\
\hline & Bachelor of Educational Administration & 1 & 4.0 \\
\hline & Bachelor of Agroecotechnology & 1 & 4.0 \\
\hline & Bachelor of Accounting & 1 & 4.0 \\
\hline & Bachelor of Law Science & 5 & 20.0 \\
\hline & Bachelor of Historical Science & 1 & 4.0 \\
\hline & Bachelor of English Language Education & 2 & 8.0 \\
\hline & Bachelor of Elementary School Teacher Education & 1 & 4.0 \\
\hline & Bachelor of History Education & 1 & 4.0 \\
\hline & Bachelor of Animal Husbandry & 1 & 4.0 \\
\hline & Bachelor of Agricultural Engineering & 1 & 4.0 \\
\hline & Bachelor of Agricultural Product Technology & 1 & 4.0 \\
\hline & Master of Animal Science & 1 & 4.0 \\
\hline & $\begin{array}{l}\text { Master of Indonesian Language and Literature } \\
\text { Education }\end{array}$ & 1 & 4.0 \\
\hline & Master of Chemistry Education & 1 & 4.0 \\
\hline & Master of Mathematics Education & 1 & 4.0 \\
\hline & Master of Educational Technology & 1 & 4.0 \\
\hline & Doctoral Economics & 1 & 4.0 \\
\hline \multirow[t]{6}{*}{ Faculty } & Economics and Business & 3 & 12.0 \\
\hline & Law & 6 & 24.0 \\
\hline & Teacher training and education science & 10 & 40.0 \\
\hline & Agriculture & 3 & 12.0 \\
\hline & Ranch & 2 & 8.0 \\
\hline & Science and Technology & 1 & 4.0 \\
\hline
\end{tabular}




\section{AUTHORS' CONTRIBUTIONS}

Ummi Kalsum as a principal investigator (PI) coordinated all research activities from drafting proposals, developing instruments to coordinating with the entire team and reviewed the data analysis process and compile this article until its completion.

Helmi Suryani Nasution as a member of the research team contributed to the data analysis and drafted this article together with PI.

Ismi Nurwaqiah Ibnu as a member of the research team contributed in developing a questionnaire and supervising enumerators and conducting data collection.

\section{ACKNOWLEDGMENTS}

The Authors wish to express the gratitude to the Jambi University Institute for Research and Community Service (LPPM) for funding this research. We also convey our high appreciation to the Rector of Jambi University and all staff who have facilitated this research activity very well.

\section{REFERENCES}

[1] WHO. (2018). Noncommunicable Diseases Country Profiles 2018. In World Health Organization. https://doi.org/16/j.jad.2010.09.007

[2] Engelgau, M., Rosenhouse, S., El-Saharty, S., \& Mahal, A. (2011). The economic effect of noncommunicable diseases on households and nations: A review of existing evidence. Journal of Health Communication. https://doi.org/10.1080/10810730.2011.601394

[3] Kementerian Kesehatan RI Badan Penelitian dan Pengembangan. (2018). Hasil Utama Riset Kesehatan Dasar. Kementrian Kesehatan Republik Indonesia. https://doi.org/1 Desember 2013

[4] Nalini, M., Oranuba, E., Poustchi, H., Sepanlou, S. G., Pourshams, A., Khoshnia, M., Malekzadeh, R. (2018). Causes of premature death and their associated risk factors in the Golestan Cohort Study, Iran. BMJ Open. https://doi.org/10.1136/bmjopen2018-021479

[5] Kivimäki, M., Leino-Arjas, P., Luukkonen, R., Riihimäki, H., Vahtera, J., \& Kirjonen, J. (2002). Work stress and risk of cardiovascular mortality: Prospective cohort study of industrial employees. British Medical Journal. https://doi.org/10.1136/bmj.325.7369.857

[6] Hasan, S. (2018, July). Ketika Dosen "Harus" Berumur Pendek.
[7] Nurdin, B. (n.d.). Dosen Berumur Pendek ? 2017.

[8] Analisis Beban Kerja Mental Dosen Teknik Industri Uundip Dengan Metode Subjective Workload Assessment Technique (SWAT). (2012).J@ti Undip: Jurnal Teknik Industri. https://doi.org/10.12777/jati.2.2.28-39

[9] Kementerian Kesehatan RI. (2015). Hasil Utama Riset Kesehatan Dasar. Kementrian Kesehatan Republik Indonesia. https://doi.org/1 Desember 2013

[10] Institute for Health Metrics and Evaluation (IHME). (2017). GBD Profile: Indonesia.

[11] World Health Organization (WHO). (n.d.). Global Health Observatory (GHO): Female life expectancy.

[12] Rubiono, G., \& Finahari, N. (2017). Dosen: Profilprofil Sederhana dalam Profesi yang Rumit. JASPT Jurnal Analisis Sistem Pendidikan Tinggi. https://doi.org/10.36339/jaspt.v1i1.35

[13] Seniati, L. (2006). Pengaruh Masa Kerja, Trait Kepribadian, Kepuasan Kerja, dan Iklim Psikologis Terhadap Komitmen Dosen Pada Universitas Indonesia. Makara Human Behavior Studies in Asia.

[14] Indriyati, T., \& Muhafilah, I. (2020). Kejadian PraSindrom Metabolik Pada Dosen Dan Tenaga Kependidikan DI. 12(1), 73-87.

[15] Utama, F., Rahmiwati, A., Alamsari, H., \& Lihwana, M. A. (2018). Gambaran Penyakit Tidak Menular di Universitas Sriwijaya. Jurnal Kesehatan, 11(2), $52-64$.

[16] Oemiati, R. (2015). Faktor Risiko Penyakit Jantung Koroner ( PJK ) Pada Perempuan (Baseline Studi Kohor Faktor Risiko PTM ) ( Risk Factors for Coronary Heart Disease ( CHD ) in Women I Baseline Cohort Study of Risk Factors for Non Communicable Disease ]). 47-55.

[17] Oktaviarini, E., Hadisaputro, S., Chasani, S., Suwondo, A., \& Setyawan, H. (2019). Faktor yang Berisiko Terhadap Hipertensi pada Pegawai di Wilayah Perimeter Pelabuhan (Studi di Kantor Kesehatan Pelabuhan Kelas II Semarang). Jurnal Epidemiologi Kesehatan Komunitas, 4(1), 35-44.

[18] Wati, I. A. S. P., Sari, K. A. K., \& Lubis, D. (2017). Perilaku Deteksi Dini Penyakit Tidak Menular pada Dosen di Fakultas Kedoketran Universitas Udayana. Arc. Com. Health, 4(1), 86-96. 